\title{
Architectural and Urban Education in Egypt in the Post Covid-19 Pandemic
}

\author{
By Sara Elrawy ${ }^{1}$, Doaa Abouelmagd ${ }^{2}$
}

\begin{abstract}
Quality of education is a global Sustainable Development Goal (SDG) to be achieved by the united nations by 2030. The covid-19 pandemic resulted in a significant problem in education worldwide and Egypt with problems related to the shift to distance learning and accessibility to technology and facilities supporting this shift. This paper aims to contribute to the currently ongoing research that asses the changes in architecture and urban education due to the Coronavirus pandemic, including the shift to distance learning in the practical courses that initially need studio work. The state of distance education via the Internet is difficult for architectural teaching curricula. Most studio environment courses require in-class follow-up. In developing countries like Egypt, not all architecture schools are equipped to move to e-learning, and most have not dealt with this before. This paper assesses student satisfaction and analyzes the entire process of distance learning in practical architectural courses during the coronavirus pandemic in Egypt. the research applies a quantitative and qualitative approach. A questionnaire was designed and distributed; 304 students from 17 Egyptian schools of architecture responded. A survey and series of interviews were completed among twelve schools of architecture in Egypt to analyze their responses during the crises and study the shift to e-learning in teaching the practical courses. The paper shows that the psychological effect and working solo from home have affected the students the most. There is a need to solve the internet problems, train the staff and the students to use the online tools for virtual classes, and provide a stable e-learning platform. The future of the traditional studio environment is under questioning. This study responds to the urgent need to evaluate the effect of Covid-19 on architecture education and to question the studio environment in the future to achieve a sustainable higher education in schools of architecture in Egypt.
\end{abstract}

Keywords: Covid-19, distance learning, architecture education, Sustainable education

\section{Introduction}

Among the 17 sustainable development goals, goal number 4 is dedicated to education, and article 3 under this goal aims to achieve a sustainable higher education. This article states that "By 2030, ensure equal access for all women and men to affordable and quality technical, vocational and tertiary education, including university" (UN, 2020). At the beginning of 2020, the world was hit by the coronavirus pandemic. The pandemic has affected higher institutions worldwide in all different disciplines, raising questions about how higher institutions will continue improving their education system and adapting to the pandemic's crises parallelly in such a short period. Moreover, to reach what article 4 stated under the same goal: "provide safe, nonviolent, inclusive, and effective learning environments for all."

1. Sara.mamdouh@f-arts.helwan.edu.eg, smamdouh.eng@gmail.com.

2.dabouelmagd@f-arts.helwan.edu.eg, dabouelmagd@gmail.com. 
Many institutions shifted towards distance learning to continue the academic year. In architecture and urban design fields, practical courses continued online in different forms, in a way that is not matching the teaching of such courses. There are different learning environments in higher education institutions; according to the course, students can be taught in lecture halls, seminar rooms, studios, or laboratories. The design-oriented artistic disciplines like architecture are inclined mainly to be taught in the studio environment. Students are provided with the knowledge, background, and common skills that allow multiple applications in various courses in the educational program. Practical courses in architecture need the studio environment that brings the student's ability to design and create, unlike theoretical courses that depend on the narrative curriculum and depends on the tutor and can be taught in the lecture halls (Dizdar, 2015 \& Yildırım et al., 2012). As the design is the main activity of practical courses in architecture, the tutor/professor works with students during the specified class time. Then, students continue to develop their work by themselves (Kurt Sevinc, 2009). Moreover, the design studio is a workspace for a collaborative, multi-sensory learning environment; a student learns to design and explore various skills (Seniz, 2009).

The primary role of the design studio has appeared since the eighteenth century in the training of architects by the French academics. During this period, art academies and applied arts schools created a model for future architects' education. The model combines theoretical teaching taught by academics in the amphitheater with practical learning in the workshops under the supervision of an architect (Masdéu \& Fuses 2017). The workshop system, called the Atelier, was the core of the curricula of these institutions. Its main advantages were the competency-based assessment system, building knowledge through critical thinking that required a great deal of cognitive processing between the architect and students. Moreover, cooperation between students of different disciplines (architects and engineers), and the practical application of theoretical concepts technical aspects. In addition to solving design problems, understanding complex relationships, and achieving aesthetic elements in the supposed project. These educational advantages became the cornerstone of a later design studio. (Sidawi 2015, Masdéu \& Fuses 2017).

After the 2020 Coronavirus pandemic, the traditional studio faces many challenges. Many questions arise significantly after the shift towards distance learning and afterward to blended learning. Can this change affect the (ILOs) of the courses? And the quality of the education system in architecture and urban fields, its alignment with the fourth global goal of sustainable development (SDG). Furthermore, what are the students' opinions about the shifting process? Moreover, what is the future of the traditional studio environment?

\subsection{Research Purpose and Limitation}

Driving from the SDGs, Egypt has also developed its 2030 vision agenda to achieve sustainable development in different fields and areas. Aim number 4 deals with "knowledge, innovation, and scientific research" (MPED, 2020). Under this aim, The Egyptian ministry of higher education and scientific research applied intensive efforts during the pandemic to guarantee academic continuity during the spring and summer semesters of 2020. However, these efforts must be assessed with the shift from the traditional system towards distance learning in the practical courses from a student perception to learn lessons that guarantee the quality and sustainability of the education 
and the students' satisfaction during the coming period.

In the academic year 2020-21, all practical courses in architecture face a significant challenge. In Egypt, the Ministry of Higher Education announced the shift to blended learning. The practical courses will take place partly on-campus. While in other countries, the practical courses will be entirely taught on-campus after applying preventative steps to guarantee staff and students safety who are using the campus. Although the research surveys schools of architecture worldwide and in Egypt, it limits itself to assess Egypt's students' satisfaction.

\section{Literature Review and GAP in Research}

\subsection{Importance of 'Traditional Architectural Learning}

Architecture students practice practical courses through various projects that are allocated to them. They can work on one project or several projects representing several stages towards a final project during the semester. The study in the studio also depends on the student's visual process to reach the final product. Students can work (a) entirely individually, (b) entirely in groups or teams, or (c) Combining the two and work, either individually or in groups. Dissimilar to other theoretical classes where students' work and knowledge are reviewed through assignments, quizzes, papers. Students' work in the studio is reviewed continuously through the critique process, either individually on each student's drawing table or in the form of sessions for a group of students. Further, student's work is also reviewed by juries/reviews (Patience Lamunu Opiyo Lueth, 2008).

The methods of critique processes, according to Nangkula Utaberta et al. (2013), are:

Individual/table critique includes a twenty to thirty-minute activity on a one-to-one dialogue between the student and the studio tutor that often runs one or twice weekly of critical comments about both the student's work.

Peer Critique, the critical review takes place by students; peer review can be in the form of comments or questions, and the tutor acting as a facilitator and feeds that discussion.

A pin-up (a "mini" review) allows for quick comments and discussion, students have enough work time in the studio, and it can happen at any time.

Group critique (Expert Critique) is the most common form of criticism sessions.

A group of students participates in one or more criticism sessions by one or more tutors. Students present their work in front of their tutors and peers and receive necessary feedback. Students can see that tutors have diverse views and can have seemingly contradictory attitudes and show disagreement among tutors in criticism.

Panel Discussion, Projects are chosen randomly or intentionally by the tutors. Discussion on Panel takes place in a participatory atmosphere. This type of discussion indirectly provides students with feedback and avoids taking criticism as personal, which is considered an effective teaching method.

Public Critique/ juries is a session in which a group of students is confronted by a "judges" committee who is mainly professors; sometimes, there is an invited professional from other departments.

They provide students with feedback; usually, this happened midway through a project and again at the final stage of a project. (see figure1) (Utaberta et al., 2013) 


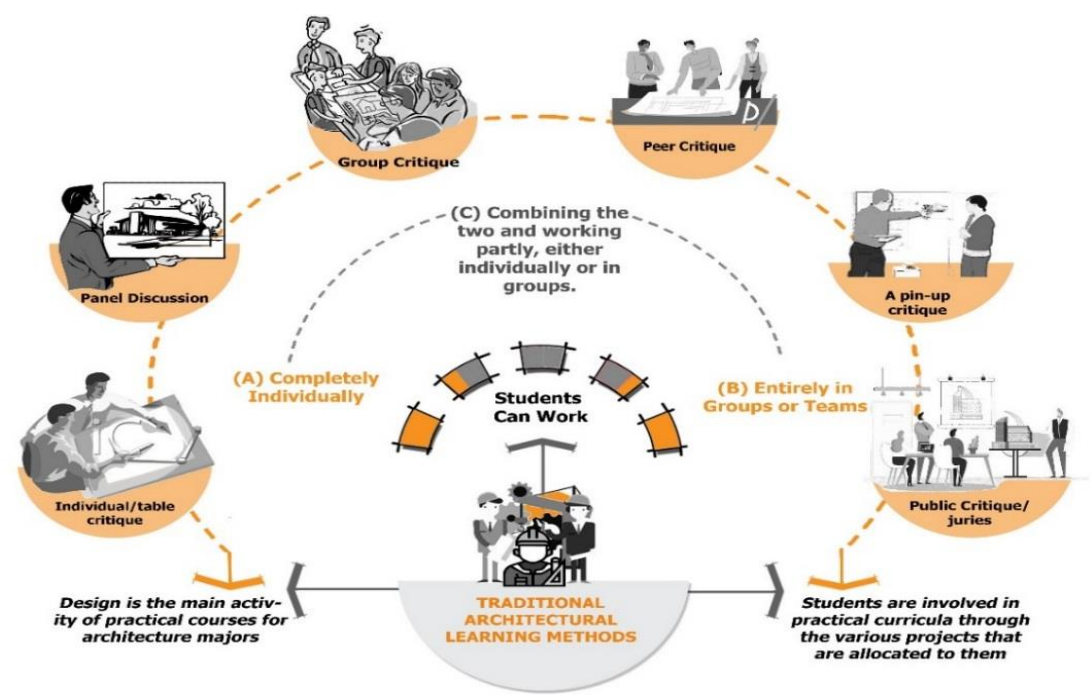

Figure 1: The methods of critique processes in architectural learning adapted by the authors

Further, more than one critique process can be applied during one stage of the project to overcome various design difficulties in the traditional design studio environment. The critique process has become an area of many investigations to associate its approaches to learning outcomes. Most studies have concluded that critical processes are among the leading interactive and indirect learning tools used in the traditional design studio. In other words, critique is often an essential means of learning method in the traditional architecture studio, allowing for the systematic development of students' work and their mindset towards design activity (El-Latif A. M. et al. 1., 2020; Gunday Gul, \& Afacan Y., 2018).

\subsection{Distance Learning and Architecture Education}

Studies related to distance learning have significantly expanded in the past decades. Distance learning is an educational method that focuses on providing teaching to students who are not physically present in a traditional learning environment, such as the classroom. Distance learning is done through new pedagogies, methodologies, and the development of internet-based technology learning (Marija Bušelić, 2012). Resorting to distance education has become necessary from some higher education institutions' viewpoints to compete with other organizations, achieve financial stability, enhance students' learning experiences, and improve learning outcomes and capabilities (Stefanovic et al., 2011). With the advent of internet-based technologies learning, which is called by some educational institutions online learning or e-learning environments, they provide possibilities for communication, interaction, and multimedia materials that enhance distance learning (ibid). The use of elearning platforms is rapidly becoming essential for a set of Architecture institutions worldwide to enhance their educational provision and meet current professional requirements. On the other hand, this learning mode faces many challenges due to a lack of resources, particularly in developing countries (Sadia Jabeen et al., 2014).

Architectural education and its practical specializations are mainly concerned with individual design creativity and training in interpreting and criticizing visual representation. 
These are not easy to teach in the lecture hall or computer lab, so it is considered a challenge in distance learning and electronically dealing with it. The main difficulty is the need for tutors and students to see simultaneously, process, and discuss projects designed in the same environment and the degree of technology availability involved in implementing a transparent communication system (Silva \& Lima, 2008). Thus, learning in architecture and its disciplines is more aligned with blended learning practices than the distance form, which combines the learning of one-to-one on-site with e-learning in the distance. Learning on site can produce a stronger sense of community, social, and cultural context of the learning environment among the students from the online course (Mizban \& Roberts, 2008).

The literature review highlights the traditional architectural learning methods and the critique processes in design studio as an essential activity for practical courses. However, with the Coronavirus crisis and its impact on higher education institutions and the emergency shift to distance education during the lockdown, it was necessary to measure the institutions' ability to adapt to these emergency conditions, especially in Egypt. The literature on the effect of this shift and the future of the design studio is still ongoing. Moreover, it was necessary to take the lead and study students' satisfaction and analyze the entire distance learning process in practical courses. Furthermore, question the future of the design studio.

\section{Research Methodology}

This research applies quantitative and qualitative approaches-the qualitative approach from the literature review, surveys, and interviews. A quantitative approach focuses on measuring and analyzing the students' questionnaire statistically.

The research has surveyed seven top-ranked international universities' official websites, including their architecture schools and their responses during spring and summer 2020. Furthermore, thirteen interviews have been conducted via phone or WhatsApp with the academic staff of 12 Egyptian public and private schools of architecture to investigate and analyze the online learning tools and methods used during the Coronavirus lockdown. Moreover, the websites, social media channels of these schools and their universities have been surveyed.

A questionnaire was developed and launched using google form during the Corona lockdown to know the extent of students' satisfaction with the emergency online learning system, the obstacles to use, especially in architecture practical courses. Furthermore, the extent to which the targeted outcomes were achieved. Three hundred four students from different public and private universities have answered it.

\section{The Impact of Covid-19 Pandemic on in Architectural Practical Courses}

Two online magazines (Building Design and Archinect) ${ }^{*}$ have communicated with

\footnotetext{
*https://www.bdonline.co.uk/news/how-covid-19-is-changing-the-face-of-architecture-schools/5105159.article. https://archinect.com/features/article/150195369/architecture-deans-on-how-covid-19-will-impact-architectureeducation
} 
several schools' deans about the rapid changes and how to respond to opportunities, challenges, and long-term implications of the COVID-19 crisis. The interviews showed different opinions; firstly, a series of virtual resources and forums would be developed to build a humane and intellectual network, to reinvent and produce students who create opportunities for themselves. Secondly, switching to online study is only a temporary measure to prevent students' academic lives from being postponed. Overall, all agreed that there would be a new experience from the pandemic's shift in teaching. The following table has concluded changes, challenges, opportunities, and potentials of the current teaching shift (table I).

\section{Table I. Opinions of the deans of architecture schools (Jim Dunton, 2020 \& Archinect,} 2020)

The rapid changes \&-Covering all aspects of courses remotely is possible, as long as computer how responding to the and a Wi-Fi connection are available and since teaching was done partially crisis online in the previous years. However, there is a need for internal knowledge related to distance learning.

- Improving working online and adapting to new software trends or platforms available for distance learning comes through intense interaction and practice.

- There have been fundamental resistance to teaching and learning online in many institutions. However, with this urgent transformation, it has been shown that online teaching methods can be adopted as an alternative that is neither worse nor better than personal, but completely different.

Challenges $\quad-$ Ensure regular delivery of teaching online, maximize the use of existing forums, and continue providing cultural and community facilities online.

- Disconnecting from the resources devoted to materials, manufacturing, and the physical effects of producing things.

- While many new teaching and learning tools and technologies are incorporated, physical space remains essential to architectural education and generators of activity and platforms for bringing people and communities together.

- Emphasizing that the expectations waited for creative thinking and careful exploration of the students were not diminished. However, it was sought to know to what extent an architectural idea could be reached with the capabilities available.

Opportunities $\quad-$ Online practices can expand their techniques to include architectural education rather than reduce or shift them away from personal processes if used thoughtfully and critically.

- Students are most creative with the materials they use to create their models when they cannot rely on their facilities.

- Think of new forms of education delivery in order to reduce costs and improve access.

- New approaches and delivery techniques may criticize the extraordinary relationship between teacher and student, which has been nurtured across generations, to suggest a more open and challenging relationship.

long-term implication - Architectural schools will rethink curricula, shapes, and how to be flexible in handling unexpected situations.

- Future learning formats and the studio design form can also be converted to hybrid or virtual delivery formats. 


\subsection{International Schools of Architecture}

In this section, seven architecture schools are examined through their university websites (see table II). These are: (Central Saint Martins (CSM), UK; Sheffield School of Architecture, UK; The Bartlett School of Architecture, UK; College of Architecture and Environmental Design, Kent State University, USA; California Polytechnic State University, College of Architecture and Environmental Design, USA; University of Florence, Architectural Sciences, Italy; Taylor's School of Architecture, Building, and Design, Malaysia). The seven schools present top-ranked architecture schools in the three most affected countries with the Coronavirus, the USA, UK, and Italy, besides an Asian example.

These schools had kept all their staff and students updated with Coronavirus news and the teaching procedures during the lockdowns. All of them except the Malaysian university have published the guidelines for students and staff. They all have an established e-learning system that helped them to cope with the emergency shift. Furthermore, they gave access to their students to online libraries and international journals.

In the USA, the architecture schools were already delivering some courses online, which led to a smooth shift. All seven international universities had carefully provided communication channels and support for their students and faculty staff to reduce anxiety and provide a smooth transition. Furthermore, there was flexibility in the final submissions. Both the British and American universities provided free access to architectural drawing programs to support the students. For the 2020-21 fall semester, the British universities showed more flexibility than the other universities for overseas or affected students who cannot join the fall semester and provided solutions to guarantee that they can follow their courses online. However, after exploring the websites, there is no evidence on how the students will follow the practical courses online.

For the 2020 fall semester, all the selected universities assured the reduction of students inside the campus, inside classrooms or studios, and taking preventative steps for students using the campus. This includes social distance, wearing masks, increasing cleaning and sanitation, placing hand-sanitizing stations around campus, and posting signage that promotes behaviors that reduce transmission. Moreover, California Polytechnic State University in the USA asks all the students who visit the campus to conduct a COVID-19 test before their arrival. Moreover, Taylor's school of architecture will not receive international students from countries recording more than 150,000 cases of Covid-19, as the Malaysian government prevents them from entering Malaysia effective 7 September 2020. Both universities did not indicate if they would give any alternative online education method to those affected students.

Universities showed a mix of remote, online asynchronous or synchronous, in-person classes, or blended/hybrid. Hybrid or blended means that students would spend part of their class time in the classroom and part of it on a computer asynchronous or synchronous. Priority for on-campus classes in all universities is for practical courses; however, the websites do not show how the universities plan to deliver these courses oncampus or apply a hybrid of blended systems. The University of Florence draws up plans for students' presence in the classrooms based on the capacity's priority is given to first grades students for in-class lectures. The following table is comparing the different universities. 
Table (II). Responses of international Schools of Architecture: 1 Type of learning system for fall 2020-21, 2 University provides full online teaching for extenuating circumstances, 3 Program available for students and educators for fall 2020-21, 4 Comments for 2020-21, 5 Announcement for coronavirus updates, 6 Guidelines/ announcement for teachers during the pandemic, 7 Guidelines/announcement for students during the pandemic, 8 Technical online support, 9 Programs used, 10 Guidance of 2021 academic year available on the website, 11 access and utilize all of the library's resources and services online. $\sqrt{ }$ means yes, $\times$ means no

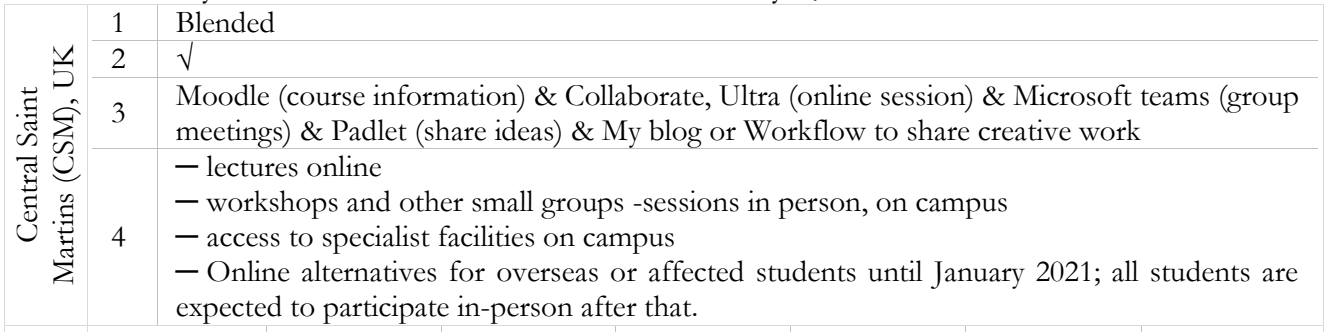

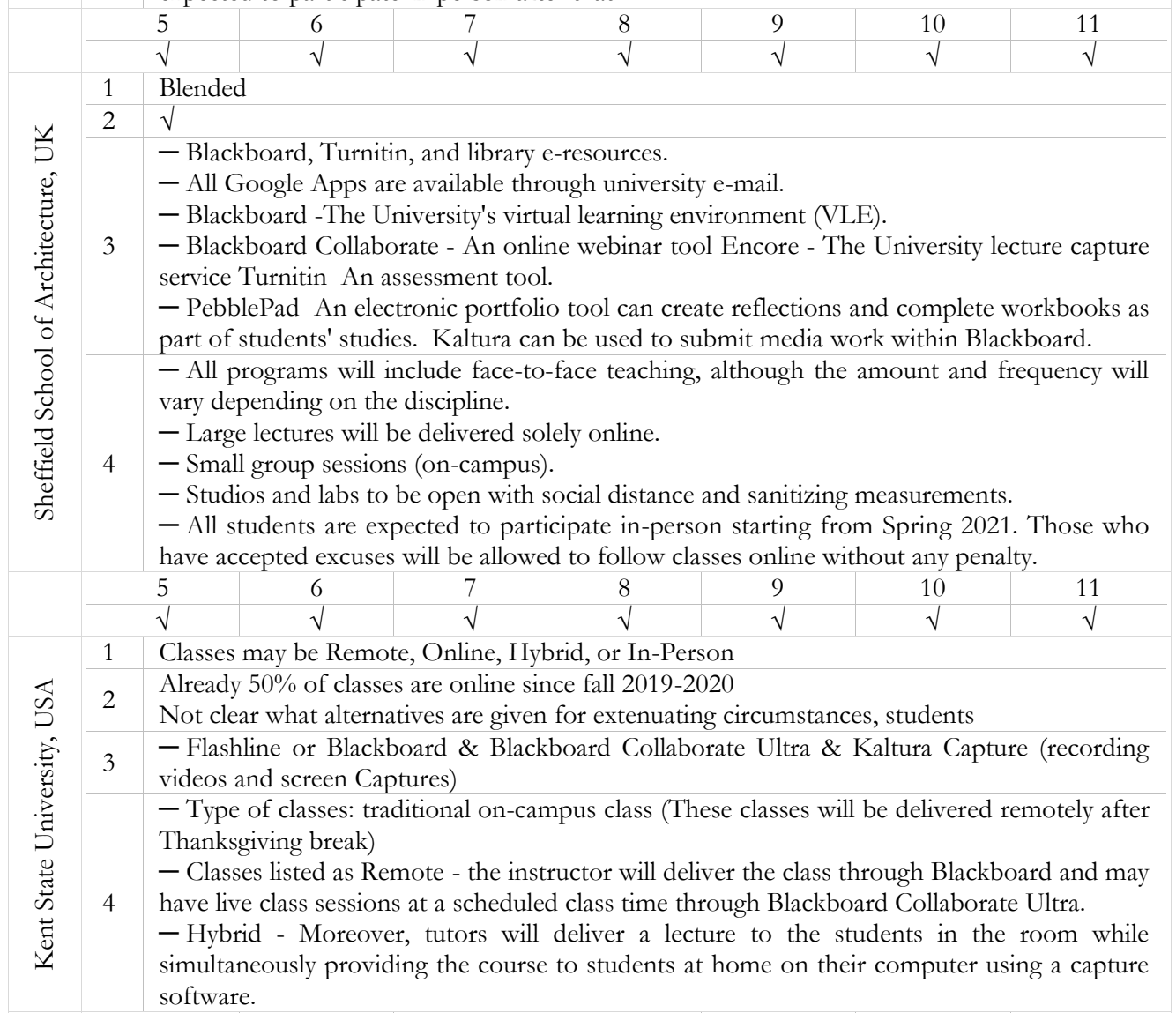

\begin{tabular}{|l|l|l|l|l|l|l|}
\hline 5 & 6 & 7 & 8 & 9 & 10 & 11 \\
\hline$\sqrt{ }$ & $\sqrt{ }$ & $\sqrt{ }$ & $\sqrt{ }$ & $\sqrt{ }$ & $\sqrt{ }$ & $\sqrt{ }$ \\
\hline
\end{tabular}




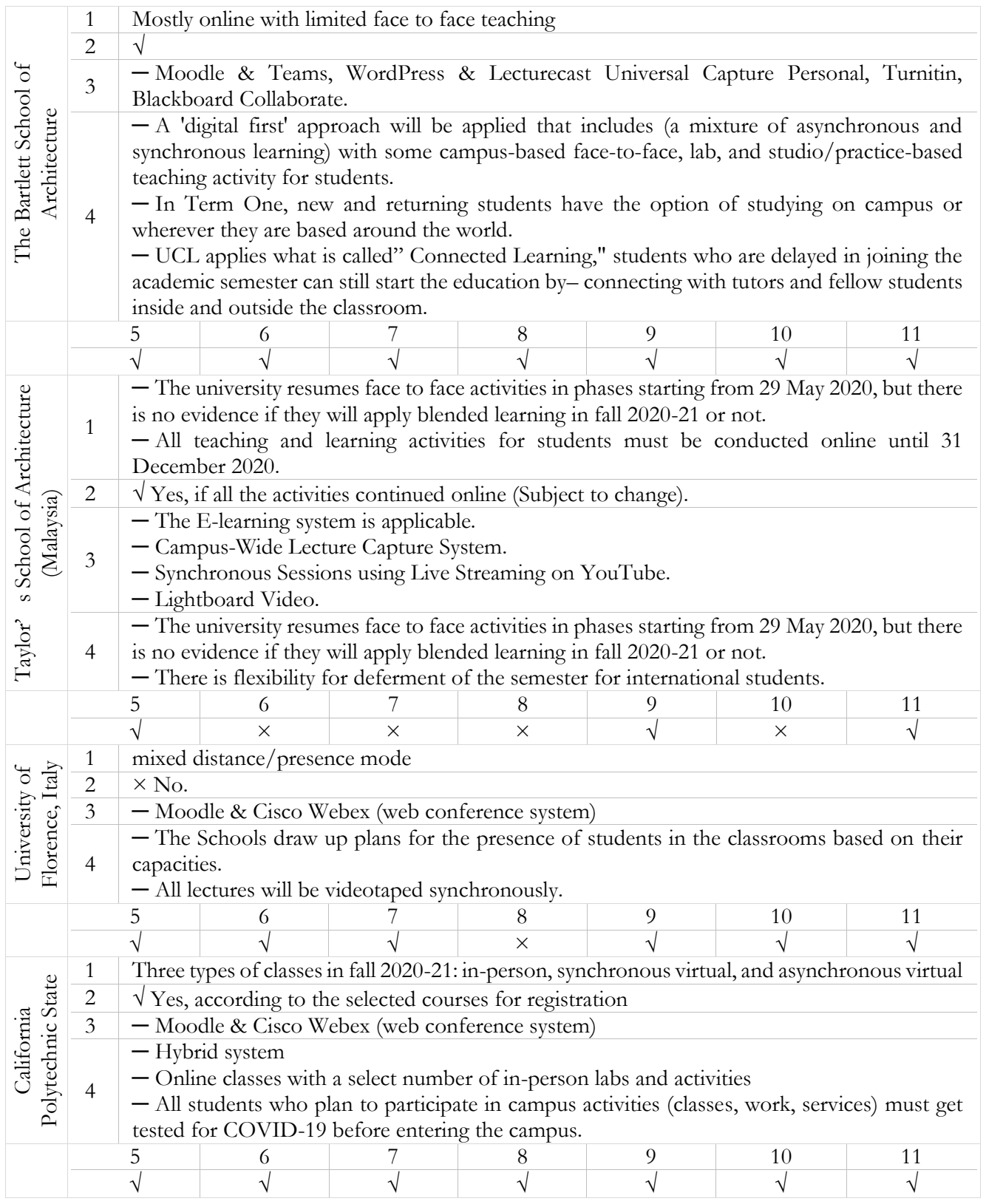

\subsection{Egyptian Schools of Architecture}

Twelve architecture schools are selected; each four represents one type of private, public university, or a higher institute. The school itself does not have a separate website, but it appeared as a department on the faculty or university website. While all of them have announced and assured implementing the exams' precautionary measures and the delivery of the graduation projects, the teaching announcements at different levels during the 
pandemic can be found only on three of their websites (AUC, BUE, and IAET). In most public universities, the shift to distance learning depended on personal efforts, as every academic staff member knew something told and taught the others. Social media, google classroom, and Zoom were the main tools used to deliver their courses. The private universities were more organized, as most of them already had an e-learning platform. However, their challenge was to deliver the practical courses online; the most common program was zoom, with its annotation tools.

Furthermore, since 2005 the Supreme Council of universities has found a national elearning center, which created an e-learning center in each university. Nevertheless, the activeness and quality of services of each center vary from one university to another. After the first wave of the pandemic, the Supreme Council of universities needed to initiate solutions for the fall semester; all the academic staff and students had a university e-mail to start using Microsoft package, including Microsoft teams, besides the WebEx Cisco initiative for video conferences.

The following table (III) sets out how these schools responded to the education process through the various tools and e-learning platforms that assist in distance learning.

Table (III). Responses of Egyptian Schools of Architecture: 1 learning system for fall 202021, 2 Programs used during the pandemic, 3 Announcement for coronavirus updates on the website, 4 Website Guidelines for tutors during the pandemic, 5 Website Guidelines for students during the pandemic, 6 Online support, 7 Social Media for announcements, 8 Guidance of 2021 academic year available on the website Till 17 September 2020, 9 access and utilize all of the library's resources and services online students/staff. Further, (A) Arab Academy for Science, Technology and Maritime Transport (AASTMT), (B) 6th October University, (C) Must Misr University For Science And Technology, (D) October Higher Institution (OHI), (E) IAET (Institute of Aviation Engineering \& Technology), (F) El-Gazeera Academy, (G) BUE (British University in Egypt), (H) GUC (German University in Egypt), (I) Architecture, Fine Arts- Helwan, (J) Ain Shams University Faculty of Engineering, (K) Faculty of Urban planning Cairo University, (L) AUC (American University in Cairo).

\begin{tabular}{|c|c|c|c|}
\hline Egyptian Schools of Architecture & \multicolumn{3}{|c|}{ ABCDEFGHIJKL } \\
\hline 1Blended, no details available. & \multicolumn{3}{|c|}{$\sqrt{\sqrt{ }} \sqrt{ } \sqrt{ } \sqrt{\sqrt{ }}$} \\
\hline Online for theoretical courses. & $\sqrt{ }$ & $\sqrt{ }$ & \\
\hline Practical classes on-campus (small groups) & & $\sqrt{ }$ & \\
\hline $\begin{array}{l}\text { In-campus for Architecture drawings and Design courses with a maximum of } 20 \\
\text { students }\end{array}$ & $\sqrt{ }$ & & \\
\hline Blended for other practical courses, one-week on-campus and another week online. & $\sqrt{ }$ & & \\
\hline $\begin{array}{l}\text { Blended with a low-density campus, where } 93 \% \text { of classes will be held online, and } \\
\text { only } 7 \% \text { will meet face to face when required. }\end{array}$ & & & \\
\hline 2Blackboard, with integrated Turnitin, Panopto & D. & & v \\
\hline Licensed Zoom & $\sqrt{ }$ & & $\sqrt{ }$ \\
\hline Microsoft teams & $\sqrt{ }$ & & $\sqrt{ }$ \\
\hline Microsoft Class Notes & & & $\sqrt{1}$ \\
\hline Student portal for final grades & & $\sqrt{ }$ & \\
\hline Moodle & $\sqrt{i} \sqrt{1}$ & & $\sqrt{3}$ \\
\hline Cisco & & & $\sqrt{1}$ \\
\hline Private e-learning platform & & & $\sqrt{1}$ \\
\hline official portal (LMS) & & & $\sqrt{ }$ \\
\hline Free basic Zoom & $\sqrt{\sqrt{1}}$ & & $\sqrt{i} \sqrt{\sqrt{ }}$ \\
\hline Google Classroom & $\sqrt{ } \sqrt{ }$ & $\sqrt{ }$ & $\sqrt{ }$ \\
\hline
\end{tabular}




\begin{tabular}{|l|l|l|l|l|l|l|l|l|}
\hline Google Drive & & & \\
\hline Facebook & & & \\
\hline YouTube Channel & & & \\
\hline WhatsApp & & & \\
\hline messenger & & & \\
\hline 3 Announcement for coronavirus updates on the website (yes) \\
no
\end{tabular}

Most Egyptian architecture schools used the ZOOM video conference application to follow up with students in practical courses either in its free or paid version. It often happened at the same time as the weekly design studio. They also sometimes recorded the correction via ZOOM and uploaded the sessions to the e-learning platform. Either official like the Moodle in AASTMT, MUST, IAET, or unofficial like google classroom and google drive in Fine Arts, Helwan University. Besides voice notes through Messenger and WhatsApp like 6th October University and October Higher Institution (OHI). Universities with an official portal/e-learning system asked their students to upload all submissions on it. As it is, too, for professors to upload all lectures and recorded presentations on it. Like, MUST, IAET, BUE, GUC, AUC, and Ain Shams University Faculty of Engineering. While other universities have dealt with the available free platform. Like 6th October University, Fine arts-Helwan, El-Gazeera Academy, and Faculty of Urban planning Cairo University. Both AUC and AASTMT has trained faculty members to use the official online learning portal. AASTMT has created a series of online courses on the YouTube Academy Education Channel, while AUC has set up training workshops.

\section{Questionnaire Analysis}

In June 2020, the authors have designed a questionnaire during the coronavirus 
lockdown, which targeted the architecture practical courses students. The questionnaire was created by google form and sent by various means over the Internet. Once the questionnaire was developed, a pilot test was performed to evaluate the questionnaire before its final release, ascertaining potential ambiguities that might affect the intended meaning. The pilot test was performed on a sample consisting of six students of the third year at the Faculty of Fine Arts, Department of Architecture, Helwan University. It was shared with them via WhatsApp. Pilot testing of the questionnaire resulted in some comments and criticisms regarding some of the questions that used vague meanings and unclear intentions. Accordingly, an Arabic translation was added for each question with an indication of each sector and an indicator to describe the question's meaning and purpose. The purpose of these changes was to maximize the chances of obtaining the right information from the final questionnaire.

The questionnaire followed a non-probability sampling method with purposive technique in the courses taught by the authors and snowball technique in other courses. By calculating the average total of 1500 students on whom the study was based in different years, the sample required for the questionnaire was calculated with Cochran formula and found approximately 306, with a margin of error of $5 \%$. The total number of responded students filled in the questionnaire was only 304 in all universities and higher institutions, with 106 males and 198 females; they varied from the second to fifth. The questionnaire aims to assesses student satisfaction and analyze their responses during the crises and study the shift to e-learning in teaching practical courses. Meanwhile, the research builds its argument that critical processes are indispensable, as traditional methods of continuously reviewing students' work.

There is a correlation between critique processes and the quality of architecture education and the (ILOs). Hence, it is not a simple challenge in distance learning. And the consequence in terms of its alignment with the fourth global goal of sustainable development (SDG). Questions for students were Structured and were divided into the following sections:

In section $A$, the students were asked about their background, experience, and lifestyle during the pandemic. This section obtains information including academic year, practical courses related to design, which taught remotely, department, and university type. Furthermore, the place of residence during this period, the extent of being affected by the COVID-19 virus, the ability to access a fixed internet connection, the type of internet connection, and the amount of data allowed, and finally, the extent of another member of the family working or learning from home.

Section $B$, the issue of distance learning, the extent of educational institutions' response to the COVID-19 pandemic, the extent to which they provide licensed applications, official platforms, educational resources during shutdown times, and how far professors or institutions provide other informal solutions for distance learning.

Section $C$, factors that affect students' satisfaction with the tools and platforms. The degree of students' satisfaction with the tools/applications used in the crisis, those tools' ability to overcome difficult design situations, especially design courses, that traditionally require a one-to-one learning and continuous review through the critique process.

Section D, assessing students' satisfaction with achieving educational outcomes, and analyze the process of distance learning during the coronavirus pandemic: The extent of students' 
satisfaction with following up the graduation project for the final year. And the research project for the rest of the years as an alternative assessment of the traditional exam. The effectiveness of distance learning compared to traditional learning, especially in architecture disciplines. The extent to which an official platform is linked to the quality of the educational process. Technological supplies and facilities are desired to be provided. References and sites that were used at that stage to develop design skills.

\section{Discussion and Findings}

\subsection{The students' background, experience, and lifestyle during the pandemic:}

The following table (IV) shows information about each academic year and practical courses related to design taught remotely, type of university, department, gender.

Table IV. Illustrates the background analysis of the participants in section A of the questionnaire.

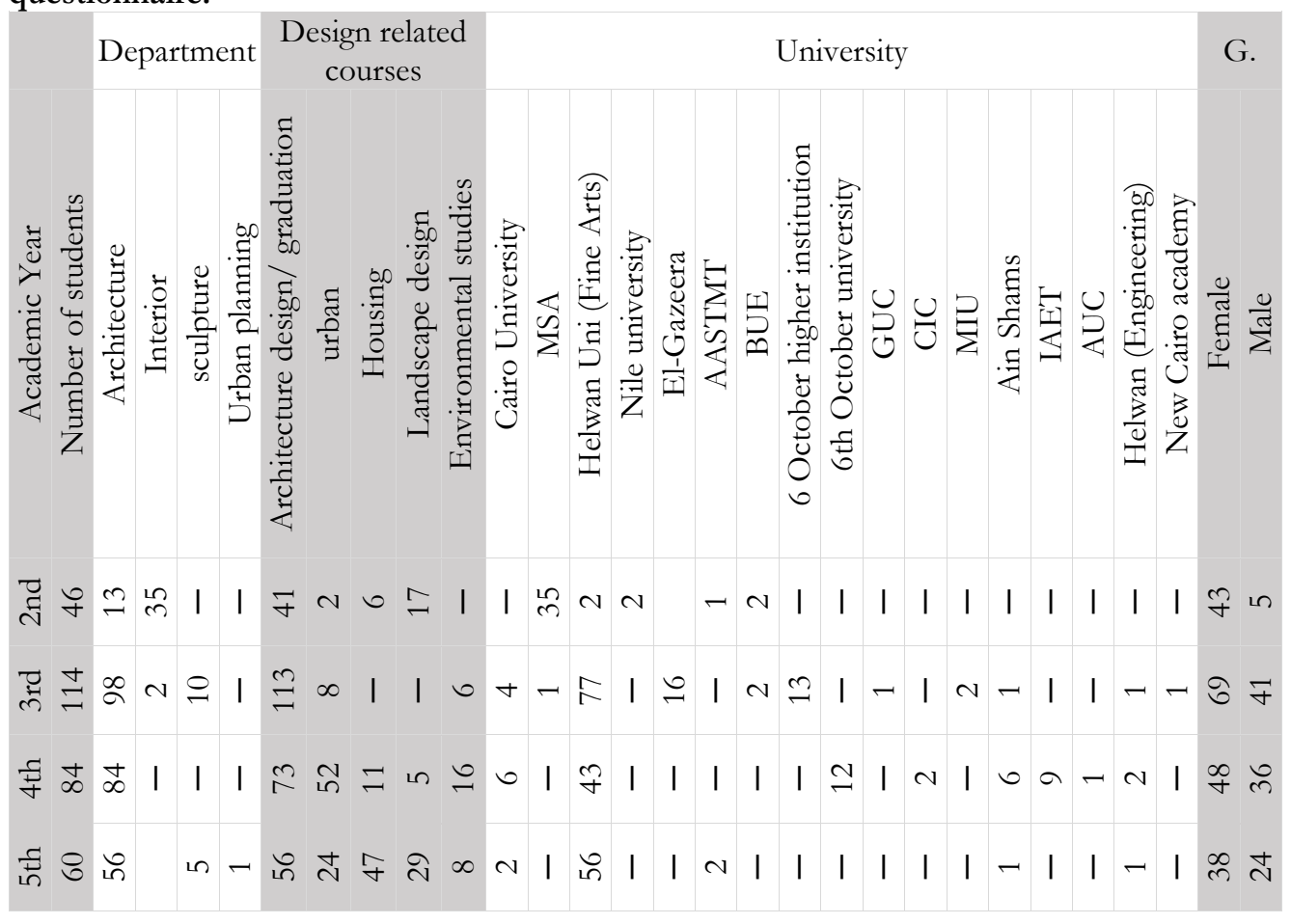

$97 \%$ of the sample said that they were staying at home during the pandemic lockdown. Moreover, $27 \%$ of students said that they were not affected by the Coronavirus. The other $73 \%$ of the students named economic and health effects, and the psychological impact. Further, by asking them if they had a stable internet connection, $74.3 \%$ answered yes, and $25.7 \%$ answered no, although they indicated that about $87.5 \%$ of them have DSL at home. $86.5 \%$ preferred that they have a limited amount of data allowed for the Internet, and about $79.6 \%$ indicated that they had family members who worked or were educated at home. 


\subsection{The educational institutions' response to the COVID-19 pandemic and students' satisfaction}

Section B aimed to understand how far the educational institutions' response to the COVID-19 pandemic and the licensed platforms' availability. It has been found that $51 \%$ of students said their institutions and universities did not provide licensed apps, official platforms, or educational resources during the lockdown, while $49 \%$ said the opposite. Rather than what the institution provided when asking students about whether the professors presented any solutions or other distance education. They were given the choice of the various alternatives, with the possibility of choosing more than one option. It turned out that the most application offered by the professors were Google Classroom, followed by ZOOM, WhatsApp, then Facebook. This means that it was the best solution at the time. While Moodle free and Skype were taken the fewest options. Furthermore, students added other applications like Telegram, E-mail, Google meets, Facetime, and iMessage.

Meanwhile, the interviews conducted with staff members of Egyptian schools of architecture, it was found that several tools for distance education were used during the Coronavirus crisis. Therefore, it was necessary to assess how far was students' satisfaction with the effectiveness of these tools. Students were advised to evaluate their efficacy compared to each other, considering only those previously tried tools. The results are as follows in figure (2).

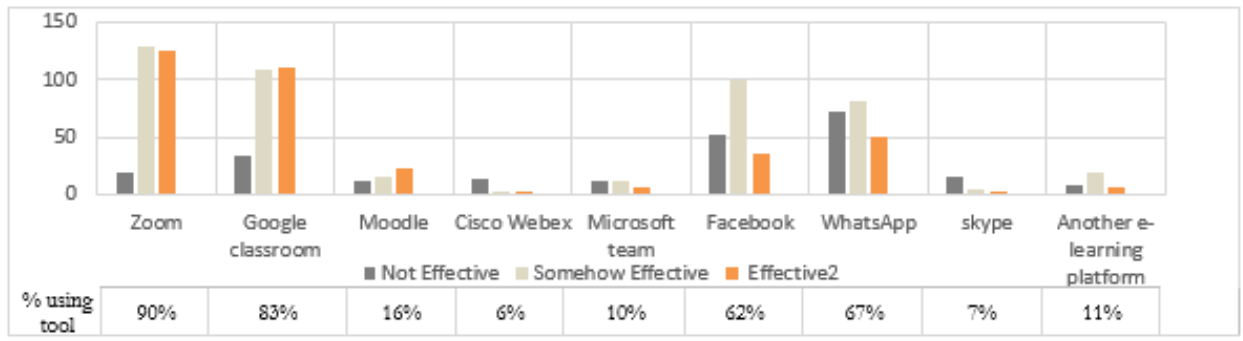

Figure 2: illustrate students' satisfaction with the tools and the percentage of students' use of the tool out of the total number of students

Students indicate that ZOOM is the most effective tool, yet students' opinions are divided. Some see that ZOOM has features like face-to-face lectures, which is significant because of the interaction provided; it also offers visual communication. Additionally, there is a property of annotating and share screens that allow understanding the lessons and asking. Students noted some problems; for instance, in free ZOOM, the session cuts every 40 minutes, resulting in lost time waiting for most students to reconnect to complete the lecture. The speed of the internet connection is not good, with instability or slow on the Internet. Sometimes, what is presented will not be accessed until the Wi-Fi connection improves, which delays or interrupts students' line of thought. Google Classroom was the second useful tool. The students agreed on some of the available points; for example, it is a good classroom organizer with strict deadlines, useful in knowing new assignments and delivering them promptly. It saves effort and money (printing projects and the like), avoiding student crowding when submitting, mistakes of forgetting the name, and losing 
projects. However, the students see that it has some problems. It cannot be considered a basic teaching system. It is only a basic system for classifying tasks, and it has nothing to do with e-learning as it lacks interaction between teachers and students and between students and each other. Also, it is limited to the size of the uploaded files.

Both Microsoft Teams and Cisco WebEx are official and are only accessible by university e-mail, and the percentage of students that used it in the sample is small. Microsoft Teams is somewhat similar to Zoom. The students indicated that they could follow up on the projects much more effectively and interactively.

Students refer to social applications such as WhatsApp and Facebook are easy to use and accessible. However, they believe that it is not a professional way to communicate. They indicated to Facebook helped through the posts and tutorial videos, recorded lectures. However, there is still a problem of ignoring responding to questions in comments, especially when there are many comments. WhatsApp is a simple one-to-one messaging app; it is not designed to deal with the many messages that more than 100 students send daily, and as a result, significant announcements may be missed. For Moodle, students find it helpful to keep them up to date with their tasks and assignment submissions, but the conflict was the small maximum acceptable file size for uploading.

\subsection{Students' ability to overcome difficulties in the design process:}

Section C measures students' satisfaction to overcome difficult design situations, especially the design courses that require critique and one-to-one education process; the students were focused on ten items: (1) Discussion between the student, tutor, and colleagues when needed. (2) Overcome design problems and exploring solutions to the design problem. (3) Understanding the comments and directions given by the tutor. (4) Produce creative projects and communicates ideas. (5) Modify and edit the design in different stages by the tutor. (6) Certainty to take the steps by the students in the design process. (7) Producing innovative activities in the design studio. (8) Manage classes and communicate with students effectively at the appointed lectures and studios. (9) Announcement for project delivery dates and meetings earlier. (10) Announcing the results of the design projects. And the results are illustrated in figure (3):

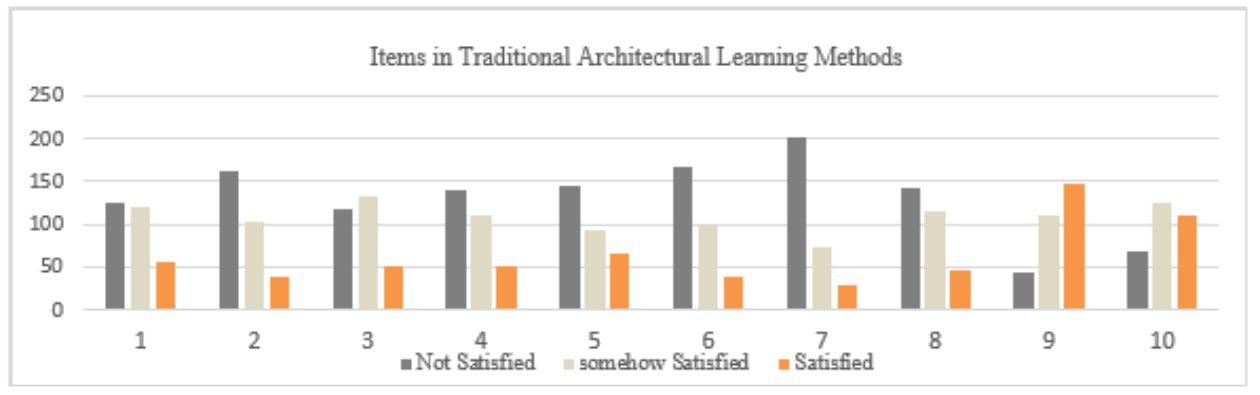

Figure 3: students' satisfaction to overcome difficult design situations

Dissatisfaction prevailed in most items, except the announcement of project deadlines and previous meetings and the declaration of design projects' results.

The students' dissatisfaction with this point means that distance classes did not allow the 
critique process practice, which was practiced freely in a traditional studio environment between students with their tutors and peers. The students are dissatisfied with overcoming design problems and exploring solutions that were occurring in critical processes, especially in an individual, a pin-up (a "mini" review), group, and panel critique discussion in the traditional studios. Moreover, the used tools in distance education did not help achieve the interaction needed to enable co-operations, understanding the tutor's given comments and directions. Modify and edit the design in various stages. As well as Certainty to take the steps by the students in the design process. This comes with the amendment and development of projects, which depend mainly on individual and group critique processes. The existence of dissatisfaction with students in online classes is evidence of a lack of optimum communication.

\subsection{Students' satisfaction with achieving educational outcomes:}

Moreover, in section D, students were asked to rate distance teaching's educational outcomes in practical design course(s). See table V and figure $4 .(1=$ refers to these outcomes not fulfilled), $(2=$ refers to these outcomes Somehow achieved), and ( $3=$ refers to these outcomes achieved).

Table V. The educational outcomes

The educational outcomes (ILOs)

\begin{tabular}{|c|c|c|c|c|}
$\begin{array}{c}\text { Architecture } \\
\text { Design }\end{array}$ & $\begin{array}{c}\text { Urban } \\
\text { Design }\end{array}$ & $\begin{array}{c}\text { Landscape } \\
\text { design }\end{array}$ & Housing & $\begin{array}{c}\text { Other } \\
\text { design- } \\
\text { related } \\
\text { course }\end{array}$ \\
\hline
\end{tabular}

a. Distance learning classes provide

$\begin{array}{llllllllllllllll}1 & 2 & 3 & 1 & 2 & 3 & 1 & 2 & 3 & 1 & 2 & 3 & 1 & 2 & 3\end{array}$
students with an opportunity to practice their creative thinking skills by sharing and developing their concepts and ideas.

b. Helping the student to develop knowledge independently and achieve the efficiency and the effectiveness of learning

c. Students were able to identify the problem, gather information, draw, edit, develop a design solution, discuss results with the lecturer and colleagues, and submit the project.

d. Distance learning classes provide an example of collaboration based on the learner's passion and professor's problem-solving experience.

e. Students were able to manage tasks, time, and resources effectively.

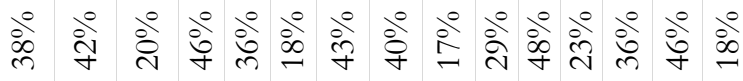

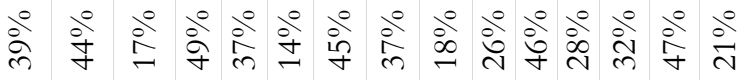

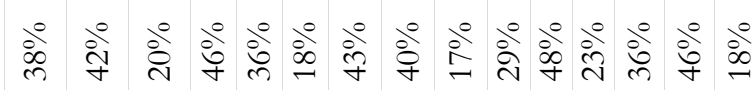

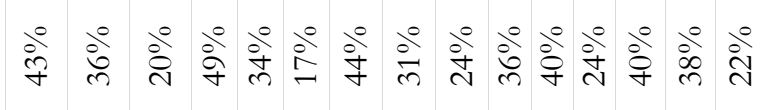

Students agreed that the distance learning classes limited their creative thinking skills by limit sharing and developing concepts and ideas. The distance education classes did not 
achieve the educational goals like traditional classes, which were based on critique methods of learning and follow-up, and continuous review of students' work, whether individual, peer, experts and the panel critique process. In terms of achieving the development of knowledge independently and achieving the efficiency and effectiveness of learning, students see that achieving it ranged between $17 \%$ to $23 \%$ in practical subjects, which is also considered the lowest percentage.

Additionally, the results indicate that students could not define the problem, gather information, draw, edit, develop a design solution, discuss the results with the lecturer and colleagues, and present the project at a rate ranging between $40 \%$ to $49 \%$. Further, Students also showed a lack of cooperation, which was available in traditional classrooms. At the same time, students were moderately satisfied with effectively managing tasks, time, and resources.

Further, this would be where the learning classes did not provide the environment and the sufficient time that the traditional class provided, especially in practical subjects. The students spent most of their time with colleagues and benefited from their peers' points of view. Also, the tutors' constant presence provides the opportunity to inquire about the information at any time. Distance learning and non-interactive electronic platforms like google classroom, for example, and not as a limitation, do not allow the student to talk, listen, represent and imitate, and react directly. Lack of face-to-face interaction was also one of the most significant obstacles.
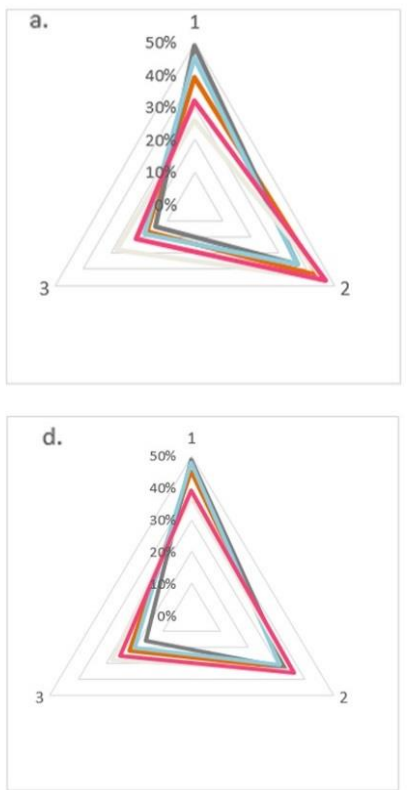
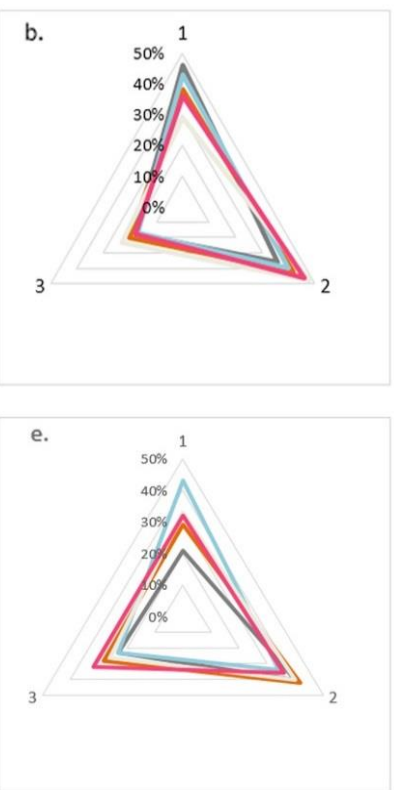
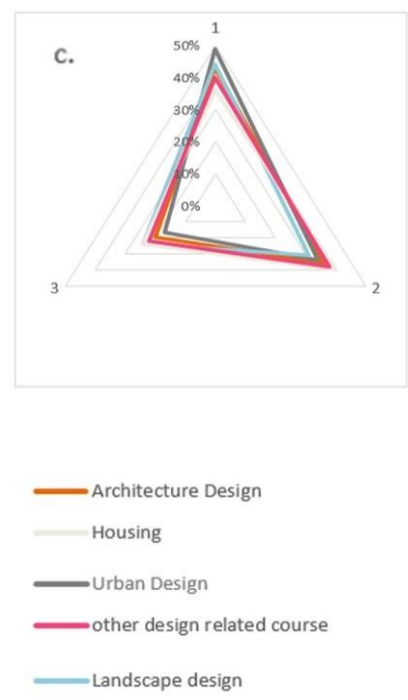

Figure 4: rating the achievement of the educational outcomes of the distance taught practical design course(s), $(1=$ Not fulfilled), $(2$ Somehow achieved $)$, and $(3=$ Achieved $)$.

Except for the final year students, the final exams were replaced with the research projects. The results concluded that $18 \%$ of all 245 students in transfer years were not satisfied, 
while $52 \%$ were somehow satisfied and $30 \%$ satisfied. Additionally, when final year students were asked about their satisfaction in pursuing the graduation project online, $32 \%$ expressed their dissatisfaction, while $43 \%$ expressed their satisfaction to some extent, and $25 \%$ were satisfied.

When distance learning and traditional learning in architectural disciplines were compared from the students' point of view, it was found that about $75 \%$ of students prefer traditional learning. They preferred critique processes that were the learning backbone of practical courses in the studio design environment. Moreover, most students have confirmed that licensed distance learning tools and platforms are crucial factors affecting tutors' delivery success. The students indicated that they need technology supplies and facilities, such as the Internet, tablet, license for applications, and software. Besides, comparing the effectiveness of distance learning with traditional learning, students were asked which is more effective; $75 \%$ of students prefer traditional learning.

Finally, when asking students if any reference was used in the design course from the Egyptian Knowledge Bank (EKB), only 10\% said yes. I have accessed and used references to the EKB; see figure (5). Furthermore, Sources and references which were used by students for gathering information and improving the design skills were: Facebook groups or pages, Wikipedia, Watching Tutorials, Scientific journals, e-books, and Pinterest, see figure (6).

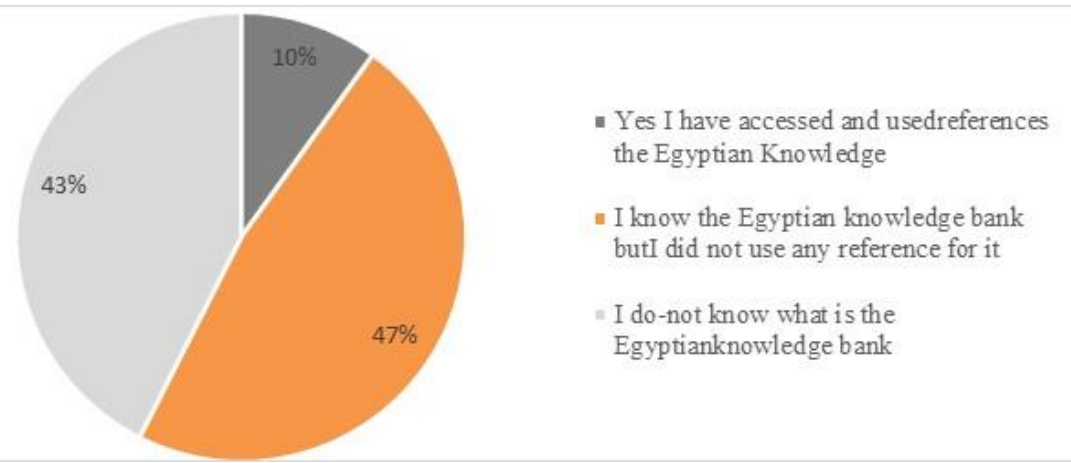

Figure 5: Student awareness of the Egyptian Knowledge Bank (EKB).

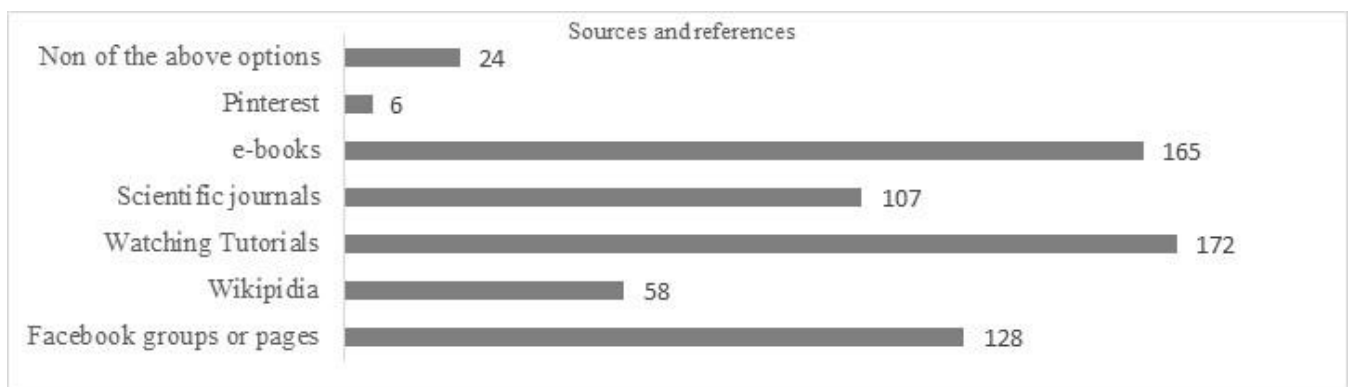

Figure 6: Sources and references which were used by students 


\section{Conclusion}

This paper focuses on the impact of Covid-19 on the quality of education in Egypt's higher institutions, focusing on schools of Architecture. Academic institutions changed the form of architecture education from studio base to online form during spring and summer 2020 and to the blended system in the academic year 2020-21.

Until the end of 2020, published literature dealt with Covid-19 and design studios in architecture schools focused on global south cases studies (i.e., India, Turkey, Jourdan, and Saudi Arabia) from qualitative and quantitative approaches. They measured the students' satisfaction on the shift from traditional to online forms (see: Varma and Jafri (2020), Ceylan et al. (2020), Ibrahim et al. (2020), and Khogali (2020)). The authors of these papers conducted primary data from educators, analyzed specific universities in their regions, and measured students' satisfaction with selected courses. The results show a smooth shift on the university levels to distance learning but less satisfaction of the students on the studiobased courses than theoretical courses. Students pointed to the need for more training and IT support. The students recorded the advantages of distance learning, such as the elearning platforms, the digital tools, and the projects' clear announcements and delivery. These results match this paper's results that present a preliminary study on architecture schools from students' perspectives in Egypt. This paper is essential to show Egyptian universities' position from a global perspective and achieve a complete overview of the shift in architecture education during and after Covid-19.

In the Egyptian case, not all schools managed the smooth shift towards online learning; private universities and public universities that had pre-pandemic e-learning platforms were faster and more successful in the shift. However, Egyptian students' satisfaction with the shift from a traditional studio environment to online learning is lower compared with the published literature.

The survey conducted shows that most of the students are not satisfied with this change, and the practical courses based on group work, peers, and panel critics are affected the most. Moreover, the pandemic's phycological effect is stronger than the virus itself; working from home affected the students hardly. The internet problems, lack of trained staff and students to use the online tools, and the lack of a stable e-learning platform in most Egyptian institutions are essential factors that must be solved to guarantee higher education's success. To overcome those obstacles, the Egyptian ministry of higher education has started upgrading the Internet inside the universities, training the staff, and initiating agreements with Microsoft and WebEx Cisco to provide a stable platform in the fall semester.

It is early to judge the future of architecture education globally and in Egypt. It requires the tutors to break out of their comfort zones into a world of intriguing and indefinite possibilities. Nevertheless, it can be said that post-COVID-19 education will be diverse, the education system's change and impact will remain. The syllabus and curriculums are modified to include the shift to online and hybrid system in the future education, mainly for theoretical contributions and online exams. Further development of software, applications, and conference programs has become essential and will continue.

It is expected that after the pandemic, the traditional studios will return but in a format that allows the delivery of theoretical components and lectures online. Several lessons from 
the pandemic are learned, we can name here: The continuity of using the educational platforms to manage the results and the students' project programs efficiently and share references, presentations, tutorials, videos, and e-book with students. The recorded lectures and panel discussions will be available to review the lectures. If there is an urgent situation, the student can contact the tutor and get an online discussion. Less paper print for final project delivery. The online juries will allow inviting national and international experts for final evolution and feedback. One of the advantages of this period is the online competitions and workshops that enriched the students' skills and allowed them to follow and join international events online. Furthermore, expand knowledge transfer and share their ideas through online webinars and seminars instead of the traditional exhibition. Nevertheless, all these advantages cannot replace the necessity of traditional studios, which allows the critic process and the design development.

Furthermore, dealing with the lack of technology infrastructure in Egyptian universities and its negative impact on students- potential technical problems must be addressed as much as possible. The following table shows the authors' action plan to improve the quality of architecture and urban education during Egypt's coming period. Some actions have already started by the Egyptian entities, but further studies should be conducted for evaluation.

Table VI. The authors' action plan to improve the quality of architecture and urban education during Egypt's coming periods according to the type of education

\begin{tabular}{|c|c|c|c|c|c|}
\hline Action & $\begin{array}{l}\text { Type of } \\
\text { education }\end{array}$ & $\begin{array}{l}\text { Priority of } \\
\text { intervention }\end{array}$ & Key actors & Outcomes & Comments and notes \\
\hline $\begin{array}{l}\text { Secure affordable } \\
\text { and fast Internet } \\
\text { accessibly to all }\end{array}$ & $\begin{array}{l}\text { Distance, } \\
\text { Blended, } \\
\text { Traditional. }\end{array}$ & $\begin{array}{l}\text { Immediate and } \\
\text { ongoing }\end{array}$ & $\begin{array}{l}\text { Universities, } \\
\text { academic institutions, } \\
\text { ministry of } \\
\text { communication, } \\
\text { ministry of higher } \\
\text { education }\end{array}$ & $\begin{array}{l}\text { Provide } \\
\text { accessibility to } \\
\text { online lectures } \\
\text { asynchronous or } \\
\text { synchronous, and all } \\
\text { research and } \\
\text { scientific references. }\end{array}$ & $\begin{array}{l}\text { Universities have started } \\
\text { improving their } \\
\text { infrastructure, including } \\
\text { internet cables. } \\
\text { However, many students and } \\
\text { staff still lack speed Internet } \\
\text { inside and outside the campus. }\end{array}$ \\
\hline $\begin{array}{l}\text { Providing } \\
\text { Licensed } \\
\text { platform }\end{array}$ & $\begin{array}{l}\text { Distance, } \\
\text { Blended, } \\
\text { Traditional }\end{array}$ & $\begin{array}{l}\text { Immediate and } \\
\text { ongoing }\end{array}$ & $\begin{array}{l}\text { Universities, } \\
\text { academic institutions, } \\
\text { ministry of } \\
\text { communication, } \\
\text { ministry of higher } \\
\text { education }\end{array}$ & $\begin{array}{l}\text { Secure and provide } \\
\text { accessibility to } \\
\text { online lectures, } \\
\text { online materials, } \\
\text { assignments, and } \\
\text { exams. }\end{array}$ & $\begin{array}{l}\text { This has already started in } \\
\text { Egypt starting from fall } 2020 \\
\text { with Microsoft teams and } \\
\text { Moodle. Nevertheless, it still } \\
\text { lacks many features as the } \\
\text { used packages are the basic or } \\
\text { free ones. }\end{array}$ \\
\hline $\begin{array}{l}\text { Providing } \\
\text { Licensed } \\
\text { software }\end{array}$ & $\begin{array}{l}\text { Distance, } \\
\text { Blended, } \\
\text { Traditional }\end{array}$ & $\begin{array}{l}\text { Immediate and } \\
\text { ongoing }\end{array}$ & $\begin{array}{l}\text { Universities, } \\
\text { academic institutions, } \\
\text { ministry of } \\
\text { communication, } \\
\text { ministry of higher } \\
\text { education }\end{array}$ & $\begin{array}{l}\text { Guarantee the } \\
\text { quality of the } \\
\text { education process. }\end{array}$ & $\begin{array}{l}\text { Especially for students in } \\
\text { architecture and urban fields. } \\
\text { For example: Auto CAD, } \\
\text { Revit, Sketch UP, ArchiCAD, } \\
\text { Grasshopper Photoshop and } \\
\text { other programs. }\end{array}$ \\
\hline $\begin{array}{l}\text { Providing } \\
\text { hardware like } \\
\text { tablets and } \\
\text { computers }\end{array}$ & $\begin{array}{l}\text { Distance, } \\
\text { Blended, } \\
\text { Traditional }\end{array}$ & $\begin{array}{l}\text { Immediate and } \\
\text { ongoing (for } \\
\text { students in } \\
\text { need). }\end{array}$ & $\begin{array}{l}\text { Universities, } \\
\text { academic institutions, } \\
\text { ministry of } \\
\text { communication, } \\
\text { ministry of higher } \\
\text { education, banks }\end{array}$ & $\begin{array}{l}\text { Guarantee the } \\
\text { quality of the } \\
\text { education process. }\end{array}$ & $\begin{array}{l}\text { Not all students can afford to } \\
\text { buy tablets and computers. } \\
\text { Computer labs in the } \\
\text { universities must be developed } \\
\text { and supported with the licensed } \\
\text { software. And be accessible and } \\
\text { open during the weekdays and } \\
\text { weekends. } \\
\text { Channels for giving student } \\
\text { loans can also be provided to } \\
\text { support them in buying the } \\
\text { needed devices. }\end{array}$ \\
\hline
\end{tabular}




\begin{tabular}{|c|c|c|c|c|c|}
\hline Action & $\begin{array}{l}\text { Type of } \\
\text { education }\end{array}$ & $\begin{array}{l}\text { Priority of } \\
\text { intervention }\end{array}$ & Key actors & Outcomes & Comments and notes \\
\hline $\begin{array}{l}\text { Developing } \\
\text { teaching methods } \\
\text { that compensate } \\
\text { face to face } \\
\text { teaching }\end{array}$ & Distance. & Ongoing & $\begin{array}{l}\text { Professors, } \\
\text { researchers, scientific } \\
\text { research centers. }\end{array}$ & $\begin{array}{l}\text { Guarantee the } \\
\text { quality of the online } \\
\text { and hybrid } \\
\text { education process. }\end{array}$ & $\begin{array}{l}\text { For example: developing the } \\
\text { teaching methods to include } \\
\text { 3D models and videos for } \\
\text { sites and buildings, using } \\
\text { architecture photography. }\end{array}$ \\
\hline $\begin{array}{l}\text { Psychological } \\
\text { support for the } \\
\text { students and staff }\end{array}$ & $\begin{array}{l}\text { Distance, } \\
\text { Blended, } \\
\text { Traditional. }\end{array}$ & $\begin{array}{l}\text { Immediate and } \\
\text { ongoing }\end{array}$ & $\begin{array}{l}\text { Universities, } \\
\text { academic institutions, } \\
\text { ministry of health, } \\
\text { ministry of higher } \\
\text { education }\end{array}$ & $\begin{array}{l}\text { Provide the needed } \\
\text { psychological } \\
\text { support and provide } \\
\text { a system for those } \\
\text { who need help }\end{array}$ & $\begin{array}{l}\text { Psychological problems and } \\
\text { depression still are taboo in } \\
\text { the Egyptian society. There is } \\
\text { an essential need to provide } \\
\text { students and staff with the } \\
\text { needed support and } \\
\text { treatments. }\end{array}$ \\
\hline $\begin{array}{l}\text { Medical support } \\
\text { for students and } \\
\text { staff }\end{array}$ & $\begin{array}{l}\text { Distance, } \\
\text { Blended, } \\
\text { Traditional. }\end{array}$ & $\begin{array}{l}\text { Immediate and } \\
\text { ongoing till the } \\
\text { end of the } \\
\text { pandemic }\end{array}$ & $\begin{array}{l}\text { Universities, } \\
\text { academic institutions, } \\
\text { ministry of health, } \\
\text { ministry of higher } \\
\text { education }\end{array}$ & $\begin{array}{l}\text { Provide medical } \\
\text { help and treatment } \\
\text { for staff and } \\
\text { students who are } \\
\text { affected by } \\
\text { COVID-19 }\end{array}$ & $\begin{array}{l}\text { There is a need to provide } \\
\text { clear protocols and guidelines } \\
\text { to seek help. } \\
\text { Improving the current } \\
\text { system. }\end{array}$ \\
\hline $\begin{array}{l}\text { The shift to small } \\
\text { classes instead of } \\
\text { large studios }\end{array}$ & $\begin{array}{l}\text { Distance, } \\
\text { Blended, } \\
\text { Traditional. }\end{array}$ & $\begin{array}{l}\text { Immediate and } \\
\text { ongoing till the } \\
\text { end of the } \\
\text { pandemic }\end{array}$ & $\begin{array}{l}\text { Universities and } \\
\text { academic institutions }\end{array}$ & $\begin{array}{l}\text { Achieve social } \\
\text { distance }\end{array}$ & $\begin{array}{l}\text { Universities and academic } \\
\text { institutions have already } \\
\text { started to shift to small } \\
\text { groups. However, new } \\
\text { academic staff members need } \\
\text { to be appointed, as the } \\
\text { current staff's pressure } \\
\text { becomes high with the extra } \\
\text { working hours and double } \\
\text { teaching loads. }\end{array}$ \\
\hline $\begin{array}{l}\text { Students and } \\
\text { Staff training for } \\
\text { distance tools }\end{array}$ & $\begin{array}{l}\text { Distance, } \\
\text { Hybrid, }\end{array}$ & $\begin{array}{l}\text { Immediate and } \\
\text { ongoing }\end{array}$ & $\begin{array}{l}\text { Universities and } \\
\text { academic institutions }\end{array}$ & $\begin{array}{l}\text { Enable the staff } \\
\text { and the students to } \\
\text { use the programs } \\
\text { and tools effectively. } \\
\text { Guarantee the } \\
\text { sustainability of the } \\
\text { education process. }\end{array}$ & $\begin{array}{l}\text { Universities and academic } \\
\text { institutions provided their } \\
\text { staff with some training. } \\
\text { However, the process is not } \\
\text { equal in all the institutions. } \\
\text { Most of the students lack } \\
\text { support and training. }\end{array}$ \\
\hline $\begin{array}{l}\text { Ongoing } \\
\text { evaluation and } \\
\text { improvements }\end{array}$ & $\begin{array}{l}\text { Distance, } \\
\text { Hybrid, } \\
\text { Traditional }\end{array}$ & Ongoing & $\begin{array}{l}\text { Universities and } \\
\text { academic institutions }\end{array}$ & $\begin{array}{l}\text { Enable sustainable } \\
\text { developments of the } \\
\text { teaching and } \\
\text { educational process. }\end{array}$ & $\begin{array}{l}\text { A continuity of evaluation is } \\
\text { needed. }\end{array}$ \\
\hline
\end{tabular}

\section{References}

Abdellatif, M., Al-Hagla, K., S., Hasan, A. (2020). Overview on the criticism process in architecture pedagogy, Alexandria Engineering Journal, Vol. 59., No. 2, PP. 753-762, ISSN 1110-0168, https://doi.org/10.1016/j.aej.2020.01.019.

Archinect (2020). Architecture Deans on How COVID-19 Will Impact Architecture Education. https://archinect.com/features/article/150195369/architecture-deans-on-how-covid-19-willimpact-architecture-education accessed 4 May 2020.

Bušelić, M. (2012). Distance Learning - concepts and contributions. Oeconomica Jadertina, Vol. 2, No. 1. ISSN 1848-1035. https://doi.org/10.15291/oec.209

Ceylan, S., Şahin, P., Seçmen, S., Somer, M., Süher, K., (2020), "An evaluation of online architectural design studios during COVID-19 outbreak", Archnet-IJAR, Vol. ahead-of-print No. ahead-ofprint. https://doi.org/10.1108/ARCH-10-2020-0230.

Dizdar, S. I. (2015). Architectural education, project design course, and education process using examples. Procedia - Social and Behavioral Sciences Vol. 176, PP. 276 - 283. 
Dunton, J. (2020). How COVID-19 is changing the face of architecture schools. build design BD Magazine, 27 March, https://www.bdonline.co.uk/news/how-covid-19-is-changing-the-face-of-architectureschools/5105159.article accessed 4 May 2020.

Gunday Gul \& Afacan Y. (2018). Analysing the effects of critique techniques on the success of interior architecture students, Int. J. Art Design Educ., Vol.37, No.3, PP. 470-479.

Ibrahim, A., Attia, A., Betaineh, A., Ali, H., (2020). Evaluation of the Online Teaching of Architectural Design and Basic Design Courses Case Study: College of Architecture at JUST, Jordan. Ain Shams Engineering Journal. 10.1016/j.asej.2020.10.006.

Jabeen, S., Din, A., and Sadiq, M., F. (2014). Students' Satisfaction from E-Learning System: A Case Study of Virtual University of Pakistan. International Journal of E-Adoption Vol. 6, No. 2, pp. 1-13. DOI: $10.4018 /$ ijea.2014070101

Khogali, H. (2020). The Effect of COVID-19 CORONA VIRUS on Sustainable Teaching and Learning in Architecture Engineering. Modern Applied Science. 14. 50. 10.5539/mas.v14n8p44.

Lueth, P. L. O. (2008). The architectural design studio as a learning environment: a qualitative exploration of architecture design student learning experiences in design studios from first- through fourth-year. Retrospective Theses and Dissertations. 15788., Digital Repository @ Iowa State University, pp. 27. https://lib.dr.iastate.edu/rtd/15788

Masdéu, M. \& Fuses, J. (2017). Reconceptualizing The Design Studio in Architectural Education: Distance Learning and Blended Learning as Transformation Factors. Archnet-IJAR, International Journal of Architectural Research, Vol. 11 No. 2, pp. 06-23.

Mizban, N. \& Roberts, A. (2008). A Review of Experiences of the Implementation of E-learning in Architectural Design Education. CEBE Working Paper, 13.

MPED. (2020). Ministry of Planning And Economic Development, Egypt Vision 2030. https://mped.gov.eg/EgyptVision?lang=en, accessed on 17 November 2020.

Seniz, C. (2009). Problematization of assessment in the architectural design. Procedia Social and behavior science, Vol. 1 No.1, PP. 2103-2110.

Sevinc, K. (2009). An analytic study on the traditional studio environment and the use of the constructivist studio in the architectural design education. Procedia Social and behavior science, Vol. 1 No.1, PP. 401-408. doi.org/10.1016/j.sbspro.2009.01.072

Sidawi, B. (2013). The Tutors' Views on The Utilization Of E-Learning System In Architectural Education. European Journal of Open, Distance, and e-Learning, Vol. 16, No. 2 1. ISSN 1027-5207

Sidawi, B. (2015). The Use of E-Learning System in Learning about Architecture: Obstacles and Opportunities. 2015 Fifth International Conference on e-Learning (econf), Manama, IEEE, pp. 117-124, doi: 10.1109/ECONF.2015.13.

Silva, N.F. \& Lima, E.M. (2008). Distance Learning in Architectural Design Studio: Two Comparative Studies with One On-site Teaching. In: Iskander M. (eds) Innovative Techniques in Instruction Technology, E-learning, E-assessment, and Education. Springer, Dordrecht, pp. 381-891. https://doi.org/10.1007/978-1-4020-8739-4_66

Stefanović, D., Drapsin, M., Nikolic, J., Scepanovic, D.,Radjo, I. (2011). Empirical study of student satisfaction in the e-learning system environment. Technics Technologies Education Management Vol. 6, No. 4, pp. 1152-1164.

UN. (2020). Sustainable Development Goals: Quality of Education. https://www.un.org/sustainabledevelopment/education/, accessed on 17 November 2020.

Utaberta, N., Hassanpour, B., Bahar, M. A., Ani, A.I (2013). A Comprehensive Learning of Architecture Education: Understanding Critique Session as Learning Process and Criteria- Based Assessment in the Architecture Design Studio. Procedia - Social and Behavioral Sciences, Vol. 102., PP. 21 - 32.

Varma, A. and Jafri, M.S. (2020), "COVID-19 responsive teaching of undergraduate architecture programs in India: learnings for post-pandemic education", Archnet-IJAR, Vol. ahead-of-print No. ahead-ofprint. https://doi.org/10.1108/ARCH-10-2020-0234.

Yildirim, M. T. Kirci, N., Özen Yavuz, A. (2012). Experience of traditional teaching methods in architectural design education: "mimesis technique". Procedia - Social and Behavioral Sciences, Vol. 51, PP. 234 -238 . 